\title{
Aspek Engineering Psychology dalam \\ Tata Letak Ruang Kantor di Industri
}

\author{
Oleh : \\ - KI Ismara \\ FT UNY

\section{Abstrak}

Kualitas proses produksi dapat ditingkatkan melalui pengembangan sistem kerja yang bersifat otomasi perkantoran. Sistem kerja terkait erat dengan ruang kantor (workplace), lingkungan kerja (work-station environmental) dan prosedur operasi dalam rangka penerapan proses otomasi per-kantoran yang sesuai dengan keadaan, kemampuan dan keterbatasan para pekerja (human factor).

Penelitian perlu dirancang dengan melakukan analisis terhadap ruang di indus-tri beserta peralatan pendukungnya. Desain ulang dilakukan terhadap fasilitas-fasilitas kerja, dengan memperhatikan faktor manusia sebagai pengguna terutama dari aspek engineering psychology. Pemeriksaan kelayakan hasil desain ulang ini melalui pertimbangan dari para ahli yang relevan (expert judge-ment), para pimpinan atau tenaga ahli di industri yang bersangkutan dan uji-coba pada kelompok pekerja kantor sebagai user. Indikator keberhasilan yang digunakan antara lain: kemudahan penerapan, kelebihan, kekurangan, peluang penyempurnaan kembali dan hambatan yang timbul dalam penerapannya. Deskriptornya mengacu kepada aspek engineer-ing psychology yaitu apakah lebih nyaman, lebih sehat dan lebih selamat dengan mengakomodasi faktorfaktor manusia (human factor). Selain itu apakah dapat meningkatkan situasional awareness, vigilance, menekan beban kerja dalam humanmachines interaction.

Hasil yang diperoleh ini adalah draft desain ulang ruang kantor beserta peralatan pendukung di dalamnya dengan lebih mempertimbangkan dimensi tubuh manusia. Dituangkan dalam gambar tata letak ruang kantor, dimensi, cakupan jangkauan yang dikemas dalain bentuk animasi. Berdasarkan penilaian para ahli menunjukkan bahwa desain hasil pengembangan memenuhi kriteria K3, sehingga ruang kantor menjadi lebih nyaman, sehat dan selamat serta menyenangkan.

Kata kunci : tata letak, ruang kantor, engineering psychology/

\section{Pendahuluan}

Perubahan tuntutan pengguna terhadap price, delivery, quality, ser- vices, safety, and clean-lines terhadap produk berbagai industri, menimbulkan iklim persaingan yang ke- 
tat. Salah satu upaya untuk memperkuat daya saing di pasar global adalah dengan peningkatan kualitas proses produksi melalul otomasi perkantoran dengan menggunakan berbagai peralatan elektronika modem. Panorama otomasi perkantoran akan dapat meningkatkan produktivitas, mengurangi biaya operasional, mengantisipasi kekurangan tenaga kerja terampil, meningkatkan kualitas produk serta memperbaiki tingkat keselamatan dan kesehatan kerja terutama untuk proses produksi yang berulang, rutin dan bersifat massal (Suzaki. 1997).

Ruang kantor yang dikembangkan berdasarkan pertimbangan aspek psikologi teknologi, sangatlah penting mengingat manusia merupakan pelaku utama dalam proses produksi. Tata letak kantor di industri harus dapat memperlancar arus pekerjaan dalam suatu alur berbagai tahapan proses produksi secara cepat, akurat, dan relevan. Selain itu juga dapat memberikan jaminan keselamatan dan kesehatan, serta ketenangan dan kenyamanan kerja sehingga diharapkan dapat mendukung efisiensi dan efektivitas proses produksi untuk peningkatan kualitas hasil (Kolarik. 1995).

Masalahnya desain bagaimana analisis, dan desami ulang sebuah ruang dengan proses otomasi perkantoran di industri yang nyaman, sehat, dan selamat, sehingga mampu meningkatkan produktivitas kerja, meningkatkan vigilansi, situasional awareness, serta mampu menekan beban kerja. Desain ruang kantor im meliputi dimensi, ukuran, cakupan jangkauan dan tata letak meja kerja, kursi, mesin atau peralatan pendukung lain yang dikaitkan dengan keterbatasan manusia pekerjaannya (human-factor).

\section{Tata Letak Ruang kantor}

Ruang kantor (work place) biasa juga disebut dengan ruangan kerja, daerah kerja (work area), atau stasiun kerja (work station). Tata letak ruang kantor meliputi penggunaan ruang untuk tempat komputer dan perlengkapan pendukung, bertujuan agar tercapai aliran bahan kerja selancar-lancamya, dengan biaya serendah-rendahnya dan pelayanan seminimum mungkin selama memproses produksi sejak dari penerimaan bahan baku sampai pengiriman bahan jadi (ILO, 1982). Sedangkan menurut Apple (1990) ruang kantor adalah ruangan yang didesain dengan baik untuk mesin atau meja kerja, peralatan pendukung dan operator, akan dapat menunjang produktivitas kerja.

Setiap pekerjaan dapat menimbulkan ketegangan (stresses) dan tekanan (strains) yang mempengaruhi tingkat kenyarnanan, kesehatan, dan keselamatan kerja, yang berdampak pada rendahnya kualitas keterampilan dan sikap kerja (Lily. 1998). Desain ulang tata letak ruang 
kantor, bertujuan agar para pekerja dapat melakukan tugasnya dengan nyaman, sehat, dan selamat dengan mengakomodasi keterbatasan gerakan pekerja, sehingga tidak menimbulkan penyakit akibat kerja, misalnya CTDs (Walters \& Sticoff, 1995). Selanjutnya proses produksi dapat berjalan dengan lebih efisien dan efektif, kualitas dan kuantitas produk akan memingkat sehingga dapat menaikkan nilaj tambah secara ekonomi bagi kantor industri yang bersangkutan.

Desain ulang; tata letak ruang kantor mengakomodasi interaksi yang baik antara komputer dan manusia, didasarkan pada data anthropometri dan keterbatasan gerakan pekerja (human-factor). Gerakan yang canggung, janggal atau ekstrim, perlu banyak pengulangan dan perlu tenaga yang berlebihan dapat direduksi dengan pengaturan tata letak ruang kantor, meliputi meșin di industri, peralatan atau pertengkapan pendukung kerja dan bahan baku Jainnya melalui pertimbangan anthropometri pekerja.

Anthropometri secara luas digunakan sebagai pertimbangan ergonomis dalam proses perancangan (desain), yang meliputi pengukuran dimensi dan karakteristik tertentu seperti bentuk, ukuran, tinggi, lebar, berat dari tubuh manusia seperti volume, titik berat, perangkat inersia dan masa dari bagian-bagian tubuh. (Wignjosoebroto, 1995:60).

\section{Otomasi Perkantoran}

Keinginan untuk meningkatkan kualitas dan kuantitas produksi, mendorong industri untuk menerapkan sistem otomasi perkantoran sampai pada pengguanaan komputer. Bames (1990), dan Pulat (1992) mengartikan otomasi perkantoran sebagai mekanisasi dalam proses produksi, untuk kepentingan kemudahan, penghematan biaya, dan peningkatan hasil produksi secara massal dan terstandar. Mesin otomasi perkantoran diartikan sebagai segala peralatan otomatis berupa, manipulator multi fungsi yang dapat diprogram menggantikan sebagian fungsi manusia untuk melakukan tugas yang melelahkan, menjemukan, dan berbahaya, bagi kesehatan. Otomasi perkantoran dalam hal ini penggunaan komputer, bertujuan untuk mendukung kenyamanan, keselamatan, keamanan, dan kesehatan, serta mengatasi keterbatasan manusia dalam proses produksi. Selanjutnya Pulat (1992) dan Sugiyanto (2000) menyatakan bahwa keberadaan otomatisasi produksi, akan sangat mempengaruhi bagaimana interaksi manusia dan mesin, sehingga akan berperan penting pula terhadap desain sistem kerja yang ergonomic, terkait dengan human computer interactions.

\section{Aspek Psikologi Teknologi \\ Psikologi Teknologi (enginee- ring Psychology) di definisikan oleh}


Wickens dan Hollands (2000) sebagai aplikasi perspektif psikologi dalam penyelesaian masalah dalam sistem desain tata letak ruang kantor. Terutama dikaitkan dengan studi pemrosesan kapabilitas informasi otak terkait dengan bagaimana manusia menggunakan suatu produk alat otomasi perkantoran (humanmachines/computer interaction). Aspek psikologi dalam hal ini meliputi human-factor, persepsi, memori, display, dan proses pengambilan keputusan. Tujuannya adalah untuk mereduksi kesalahan dalarn mengoperasikan peralatan otomasi perkantoran tersebut, meningkatkan produktivitas kerja, menjamin keselamatan dan kesehatan saat kerja dengan peralatan tersebut, serta meningkatkan kenyamanan saat manusia berinteraksi dengan alat tersebut. Di sisi lain, perpektif psikologi teknologi akan membantu mengaplikasikan knowiedge management dalam mendesain system yang dapat mengakomodasikan keterbatasan performansi manusia dan keunggulan manusia sebagai operator dalam proses kerja (human-factor dalam rangka man-machine/computer interaction).

Sebagai contoh adalah pengoperasian mesin di industri dengan di industri yang relative modern, biasanya sudah dilengkapi dengan display digital atau monitor layar sentuh sebagai interface dalam human-computer interaction. Karyawan yang sudah terbiasa dengan operasi mesin secara manual, akan merasa bahwa mesin ini sulit, mudah rusak, dan banyak perintah atau tombol yang tidak mudah untuk dipahami atau diingat. Seharusnya yang terjadi adalah sebaliknya, begitu melihat barang tersebut akan membuat karyawan memiliki persepsi yang positif dan tertarik terhadapnya, bahkan dapat membangkitkan motivasi untuk bekerja serta kuriositas yang tinggi. Selanjutnya timbul asumsi bahwa alat baru tersebut terlihat menyenangkan, akan banyak membantu, dan mudah dioperasikan. Perasaan yang timbul adalah seperti saat mendapatkan handphone baru yang memiliki fasilitas lengkap dan bentuknya indah. Pengguna akan mendapatkan banyak informasi dari fitur atau display digital dan suara yang timbul saat mesin beroperasi. Suara memberitahukan bahwa akan mulai beroperasi, display menunjukkan konfigurasi gerakan, waktu dan berbagai informasi lain yang dibutuhkan dengan segera. Hal tersebut akan memberikan pengalaman yang memuaskan, menyenangkan, dan mendorong untuk lebih intens untuk menggunakannya kembali.

Perasaan semacam ini pertu dikembangkan, dihayati, atau dirasakan secara mendalam. oleh para desainer tata letak ruang kantor di industri beserta produk peralatan otomasi pendukungnya, yaitu menghayati apa perasaan pengguna saat 
is

mulai melihat, memegang, dan mengoperasikan alat tersebut. Desainer saat mulai menganalisis, dan merancang, sebaiknya juga berusaha untuk mengerti persepsi, system nilai dan asumsi yang dimiliki calon pengguna. Hal ini terkait erat dengan kultur pengguna, tingkat pendidikan, dan pengalaman kerja seharihari. Kekurangan dalam hal ini, akan menyebabkan tahapan pemrosesan informasi pengoperasian alat berteknologi otomasi perkantoran dikaiłkan dengan tata letak ruang kantor tersebut oleh pengguna tidak dapat optimal, karena desainer secara psikologis, belum menempatkan 'diri sebagai calon pengguna.

Ruang kerja dan produk peralatan berteknologi otomasi perkantoran yang sebenamya didesain untuk orang Eropa atau Amerika, sering kita manfaatkan dan gunakan secara langsung. Di mana ukuran, jangkauan, berat, bentuk, warna, model, bahasa, symbol, kode, jenis tombol, dan urutan pola pikir atau logika cara mengoperasikannya mungkin lebih mendekati kebiesaan dan budaya kerja dari daerah asalnya. Akhirnya, lembaga pelatihan pengembangan sumberdaya manusia. kita menjadi kerepotan untuk membuat the man fit to the task of machine. Akibat dari kesenjangan ini adalah interaksi manusia mesin' komputer tidak selaras, ada tuntutan kognitif dan psikologis terhadap pekerja yang terlalu tinggi, sehingga pe kerja akan mudah melakukan kesalahan, stress, bored, fatigue, bahkan menimbulkan kondisi unsafe, missalnya terjadi cumulative disorder di beberapa bagian organ tubuhnya. $\mathrm{Hal}$ tersebut menjadikan usaha peningkatan performansi menjadi sangat mahal dari pada seharusnya. Di bawah ini terdapat beberapa aspek yang perlu dipertimbangkan dalam desain suatu peralatan otomasi perkantoran yang secara psikologis disebut sebagai user ftiendly (Ismara.2005).

\section{Pendekatan penelitian}

Penelitian ini menggunakan pendekatan research (analysis) and design. Analisis dan desain dalam penelitian ini hanya akan dibatasi sampai pada tahap uji coba kelayakan draft hasil desain. Studi kasus yang digunakan adalah tiga industri menengah yang telah mulai menerapkan teknologi komputer dalam proses produksinya.

Tahap analisis terdiri dari kegiatan pengamatan, observasi partisipan yang mendalam, pengumpulan data dan analisis data. Data tersebut berupa. gerakan dalam proses kerja, ukuran tubuh (anthropometr), atau spesifikasi keterbatasan atau kolebihan dari manusia. Data juga meliputi tentang dana, mesin, bahan baku, metode, waktu, dan informasi ( $m a n$, money, material, machines, methode, time ang information) yang relevan dengan tujuan dilakukannya de- 
sain (KI. Ismara, 2002). Pengurnpulan data menggunakan pendekatan kualitatif dengan metode observasi, wawancara dan analisis terhadap data dokumentasi. Tahap ini dilengkapi dengan pendekatan kuantitatif yaitu pengukuran secara langsung dimensi ruang kantor, peralatan pendukung, dan pekerjaan.

Desain dalam hal ini diartikan sebagai rancang bangun, hasilnya dapat berupa prosedur, gambar sketsa, skema, gambar fisik, konstruksi, sistem atau deskripsi suatu kegiatan yang disesuaikan dengan karakteristik dan kernampuan manusia penggunanya (KI Ismara, 2002), yang dituangkan dalam bentuk animasi. Animasi merupakan komponen multimedia yang berhubungan dengan perangkat lunak untuk pengembangan cara menyampaikan informasi kepada pengguna. Animasi menampi!kan perubahan gambar satu ke gambar berikutnya sehingga dapat membentuk atau menirukan suatu gerakan dan suara tertentu (Sutopo, Ariesto Hadi, 2002).

Tahap desain terdiin dari merancang, mendesain, mempresentasikan, dan menguji coba hasil desain secara teoritik dengan subyek individual dan kelornpok dilengkapi dengan angket atau komentar tertulis dari subyek. Tahap ini menggunakan pendekatan ECCS (eliminate, combine, change, simplify). Rancangan ini meliputi desain ulang tata letak ruang kantor yang dikaitkan dengan sistern otomasi perkantoran produksi. Penuangan hasil rancangan ini menggunakan software animasi 3D Max, 3D home Architect, Visio Drawing, Corel Draw dan Macromedia fdi industrih Max.

Tahap ujicoba, meliputi pemeriksaan atau. konfirmasi (audit trail) kelayakan draft hasil desain ulang melalui pertimbangan dari para ahli yang relevan (expert judgement), khususnya para pimpinan atau. Tenaga ahli di industri yang bersangkutan dan ujicoba pada kelompok kecil yaitu peserta pelatihan pekerja dan supervisor kantor di industri sebagai pengguna. Indikator sebagai tolak ukur keberhasilan yang digunakan antara lain: kemudahan penerapan, kelebihan, kekurangan, peluang penyempurnaan kernbali dan hambatan yang timbul dalam penerapannya. Descriptomya mengacu kepada aspek engineering psychology yaitu apakah lebih nyaman, lebih sehat dan lebih selarnat, dengan mengakomodasi faktor-faktor manusia (human factor). Selain itu apakah dapat meningkatkan situasional awareness, vigilance, menekan beban kerja. Usulan dan kornentar dari tahap ini akan digunakan utuk menyempumakan kembali desain ulang tata letak ruang kantor, agar lebih sesuai dengan harapan calon pengguna. 
Pembahasan Hasil Desain Ulang

Berdasarkan data hasil penelitian dan analisis maka ruangan dibagi menjadi ruang kerja dan quality control, agar bahan kerją yang sudah selesai, tidak perlu dibawa. ke luar gedung untuk diperiksa. Ruang Quality Control diatur dalam konfigurasi U/L untuk keleluasaan gerak pe- kerjaan. Ruangan ini dilengkapi dengan poster yang bersifat provokatif dan preventif, berupa manual operasi kerja terstandar, informasi tentang K3, prosedur evakuasi keadaan darurat, $5 S / 5 R$ dan peningkatan kualitas kerja.

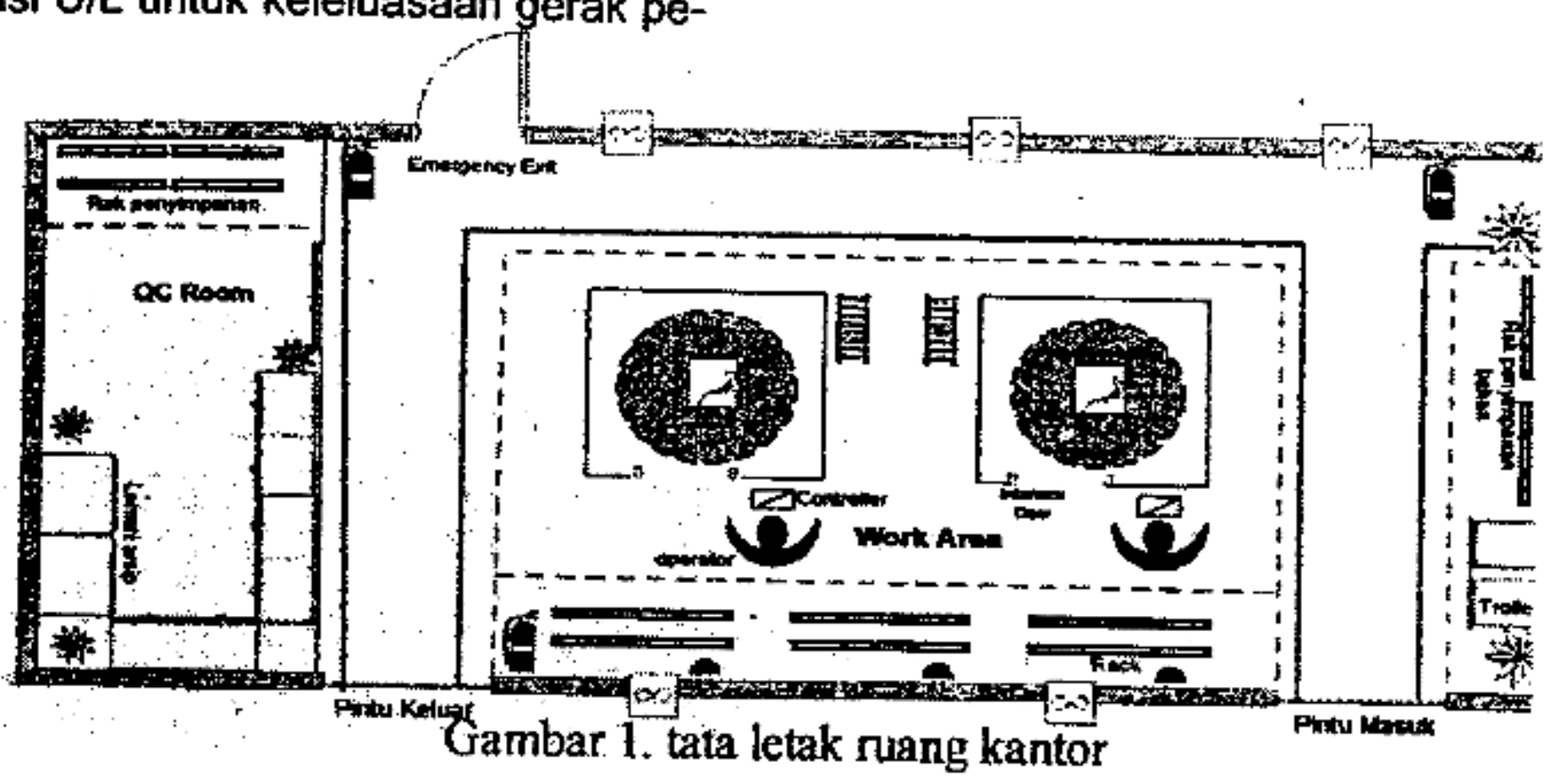

Luas ruangan kerja di industri yang dibutuhkan adalah $12 \times 5 \mathrm{~m}$ dimana setiap kornputer dipisahkan oleh safety fence. Pagar pengaman (safety fence) dibuat dari bahan yang tembus pandang tetapi memenuhi persyaratan keamanan yang direkomendasikan. Pagar pengaman ini secara otomatis akan menutup ketika proses kerja berlangsung. untuk mengisolasi pekerja dari hazard yang ada. Tiap peralatan yang berbahaya seperti mesin foto copy, perajang kertas, dan mesin pence- tak, diternpatkan pada satu ruangan tertentu dilengkapi dengan saluran udara untuk mengeluarkan paparan gas dan debu yang dihasilkan.

Dimensi untuk tiap ruang kerja otornasi perkantoran di industri, adalah 3,296 (l)m $\times$ 3,945 (p)m $\times 3,0$ (t)m. Tinggi untuk saluran udara adalah $4,620 \mathrm{~m}$. Antar ruang satu dengan lainnya diberi jarak $0,5 \mathrm{~m}$ dan jarak dari tembok ke komputer sekitar I m untuk keleluasaan pergerakan pekerja. Pengoperasian di industri di industri melalui pemasukan 
data di atas bangku, dengan tinggi $1025 \mathrm{~mm}$ dari atas permukaan lantai, sesuai kenyamanan operator. Rentang dimensi kerja sebesar $304,6-426,7 \mathrm{~cm}$, Perbedaan keting- gian tempat penyimpanan dengan permukaan meja kerja akan memudaskan dalam perpindahan barang dengan memanfaatkan gravitasi.

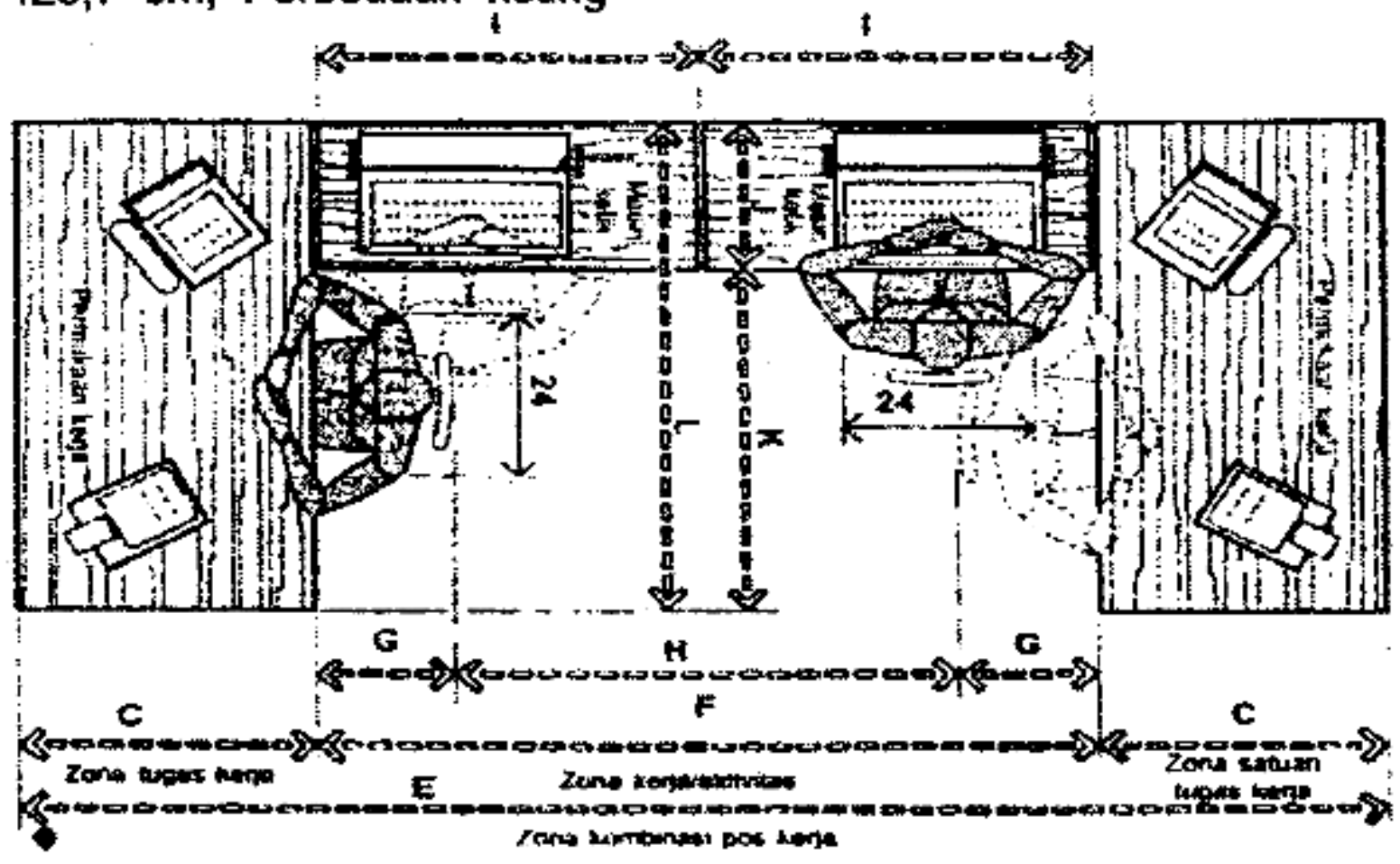

\section{Gambar 3. Desain ruang Quality Control}

Hasil desain di atas dituangkan menjadi gambar animasi tata letak ruang kantor beserta peralatan pendukungnya. Hasil tahap desain ini merupakan draft kasar yang masih perlu dikonfirmasikan tingkat kelayakannya, agar dapat lebih sesuai dengan harapan calon pengguna. Pemeriksaan kelayakan hasil desain secara audit trail dengan melalui pertimbangan referensi dari para ahli yang relevan, dan para pimpinan atau tenaga ahli di industri yang bersangkutan. Indikator sebagai tolak ukur antara lain adalah kemudahan penerapan (applicative, adaptability andflexibility), kelebihan (strengh), kekurangan (weakness), peluang penyempurnaan kembali (opportunity) dan hambatan yang mungkin timbul dalam penerapan (threaf). Deskriptomya adalah lebih nyaman, sehat dan selamat, dengan mengakomodasi faktor-faktor manusia (human factor). Selain itu apakah dapat meningkatkan situasional awareness, vigilance, dan menekan beban kerja. Usulan atau komentar dari tahap ini akan digunakan untuk penyempurnaan kembali desain tata 
letak ruang kantor tersebut. Selanjutnya hasil desain sudah dapat dianggap layak untuk digunakan sebagai rekomendasi bahan penentu kebijakan di industri tersebut. Layak pula untuk diimplementasikan dan digeneralisasikan ke proses yang sama di industri lainnya.

Kemudahan penerapan (aplicative, adaptability and flexibility) desain tersebut relatif mudah, karena semua kebutuhan sumber daya pendukung baik informasi, teknologi, periengkapan, bahan baku maupun tenaga ahli yang terkait telah tersedia dan mudah ditemukan di pasaran Indonesia. Informasi tentang pedoman dan persyaratan desain pun mudah didapatkan. Kelebihan (stre$n g h$ ) desain tata letak ruang kantor yang terintegrasi ini akan dapat menghemat biaya. Baik itu biaya operasional ataupun biaya perawatan yang bersifat fixed atau variabel. Kaidah ergonomi akan terpenuhi, dengan demikian kenyamanan; kesehatan dan keselamatan kerja akan terpenuhi pula. Kelebihan selanjutnya adalah kemungkinan peningkatan produktivitas kerja akan tercapai, karena pekerja akan merasa senang, nyaman, aman, dan sehat.

Kekurangan (weakness) desain tata letak ruang kantor ini akan menimbulkan permasalahan baru yang saling mengkait, yang biasanya dari sumber daya manusia, meliputi perilaku yang kurang disiplin, kurangnya kesadaran diri dan mo- tivasi kerja yang rendah (attitude and achievement motivation), hal ini terkait dengan psikologi perilaku pe kerja dì industri.

Peluang

kembali (opportunity) setelah dapat umpan balik dari para ahli sa. ngat memungkinkan untuk dilakukan. Penyempurnaan kembali sangat terkait erat dengan banyak variabel sumber daya pendukung dimana industri tersebut berada. dan perlu penyesuaian lebih lanjut.

Hambatan atau tantangan (threat) yang mungkin akan timbul dalam penerapan rekomendasi hasil desain adalah investasi dana yang relatif besar dan kurangnya ketersediaan tenaga ahli yang terkait, baik yang memiliki penguasaan spesifik, spesialis, maupun generalis yang mendukung penerapan hasil desain tersebut.

Deskriptor lebih menyenangkan, nyaman, sehat dan selamat; karena ruang gerak pekerja menjadi lebih leluasa dan mengacu pada aspek ergonomis, sehingga memperkecil kemungkinan resiko berbagai macam penyakit atau kecelakaan kerja. Semua mesin, bahan baku dan peralatan pendukurig tertata secara rapi dan teratur sesuai dengan kebutuhan sehingga mudah dijangkau, pencahayaan dan suhu yang tepat, pengoperasian mesin maupun peralatan lain menjadi lebih mudah. Sehat dan selamat karena sumber potensi bahaya dapat disolasi, dieli- 
minasi dan diproteksi dengan lebih baik, ketersediaan alat pelindung diri yang lengkap merupakan jaminan keselamatan keda yang memadai. Pekerja yang terjamin kesehatan dan keselaniatan kerjanya, akan merasa nyaman dalam bekerja, sehingga dapat meningkatkan produktivitas kerja. Kenyamanan ditentukan oleh suasana, warna dinding, kebersihan, kerapihan, dan keindahan tata letak ruang kantor. Kenyamanan, keseha* tan dan keselamatan kerja merupakan motivasi urutan kedua menurut pendapat Maslow. Secara menyeluruh desain terhadap ruang Kerja yang dilengkapi proses otomasi perkantoran di industri ini bertujuan untuk dapat mengendalikan potensi sumber bahaya yang mengancam kenyamanan, kesehatan dan keselamatan kerja. Sehingga desain terhadap ruang kantor ini harus disinkronkan dengan lingkungan kerja dan prosedur kerja yang terkait.

Setiap informasi dan kondisi tata letak ruang kerja dan peralatan akan memberikan stimulus melalui sensor atau reseptor tubuh (mata, telinga) untuk dapat meningkatkan akses ke otak pengguna. Rangsangan dari luar yang ditangkap oleh mata atau telinga misalnya, disalurkan oleh syaraf penerima (reseptur) ke otak, kemudian setelah melalui proses kognisi dan menyimpanan dalam memori jangka pendek, serta pembandingan ciengan memori jangka panjarig, oleh neurotransmitter, otak akan memerintahkan kepada otot untuk bergerak. Stimulus yang menyenangkan biasanya akan membangkitkan respon yang menyenangkan pula. Misalnya suara mesin peralatan kantor yang tidak bising dan menyenangkan akan membuat kita dengan senang pula untuk berinteraksi dengan mesin komputer atau mesin facsimile tersebut. Berarti untuk desain tata letak ruang kantor yang memberikan rangsangan kepada organ tubuh lainnya, misalnya menimbulkan suara, sinar, atau getaran, sebaiknya disesuaikan dengan kesenangan (pleasure), kenyamanan, dan keamanan pengguna. Hal ini akan menimbulkan pengalaman penggunaan ruang dan peralatan mesin yang sangat memuaskan pengguna.

Di memori jangka panjang atau pendek, terjadi proses pemberian persepsi berdasarkan penalaran, argumentasi, identifikasi, pembandingan, system nilai, pengalaman, dan pengetahuan yang dimiliki. Kemudian akan terjadi proses penginterpretasian, dan pemberian makna terhadap rangsangan yang masuk ke otak melalui indera (sensor). Persepsi yang telah melalui proses kognisi tersebut di atas, akan membuat pengguna memberikan respon sebagai umpan balik secara spontan, baik berupa tindakan, komentar, atau raut wajah dan bahasa tubuh (cues) lainya. Hasil persepsi ini akan memberikan dorongan kepada 
pengguna apakah akan menganggap komputer dan peralatan perkantoran lainnya, sebagai bahaya yang mengancam atau sebagai sesuatu yang bermanfaat, atau menimbulkan rasa ingin tahu (kuorisitas dan atensi), atau bahkan sebaliknya menjadi antipati. Persepsi inilah vang akan menentukan motif respon atau tindakan pengguna (ingat respon fight or flight), selanjutnya akan dapat membuat calon pengguna menjadi pengguna yang fanatik, hanya dengan mengolah persepsi ini atau Sebaliknya. Desainer telah memiliki data yang cukup lengkap terkait bagaimana calon pengguna akan mengasuransikan, mempersepsikan atau harapan pengguna terhadap tata letak ruang kerja dan peralatannya sebagai hasil desain. Hal mi terkait erat dengan kultur, pendidikan, jenis kelamin, sistern nilai dan asumsi dasar, keterbatasan manusia serta antropometri atau ukuran tubuh calon pengguna (human factor).

Suatu proses desain tata letak ruang kantor, telah mengakomodasi bagaimana proses psikologi pengguna saat pengambilan keputusan dalam kegiatannya sehàri-hari yang terkait dengan penggunaan mesm dan peralatan di dalam ruang. Bagaimana pola pikir, tahapan proses pengambilan keputusan terkait dengan pengolahan sensor, argumentasi, persepsi, sampai atensi. Saat pengguna mengalami suatu masalah, apa yang terlintas pertama kali dalam pikirannya, misalnya cara penyelesaian, mengapa. apa atau siapa yang akan dapat membantu un. tuk menyelesaikan, bagaimana. $\mathrm{Ca}$ ranya, atau apa persyaratan yang harus, dipenuhi untuk itu (Sternberg. 1999). Semakin pendek dan cepat proses pengambilan keputusan dengan menggunakan otak kanan, kernudian akan semakin cepat respon dan tindakan yang diberikan terkait dengan nama peralatan dan tindakan yang memungkinkan di dalam tata letak ruang kerja, berarti memiliki fleksibilitas tinggi. Desainer tata letak ruang, bertujuan membantu. pengguna untuk dapat mengambil keputusan dengan cepat, akurat, relevan dan mengarah kepada, seringnya penggunaan mesin dan peralatan yang telah diakomodasikan ke dalam. tata letak ruang kerja yang didesain ulang. Hal tersebut terkait erat dengan kepuasan pengalaman pengguna selama mengoperasikan dan bekeda di ruang, misalnya nyaman, senang, aman, atau mudah untuk dioperasikan peralatan kantor dan lain-lain.

Vigilansi merupakan atensi pengguna terhadap produk yang dapat berlangsung secara terus menerus, walaupun sinyal informasi yang diberikan produk tidak ajeg, tidak tertentu dan. tidak dapat diprediksi kapan munculnya. Misalnya saat operator harus memperhatikan mesin atau peralatan perkantoran di industri, dan belum. tahu kapan akan 
ada sinyal bahwa proses produksi telah hampir selesai, atau bahan baku kertas atau tinta telah hampir habis, atau kapan akan ada pesan melalui jaringan komputer yang masuk. Dalam. hal ini yang terjadi adalah pengguna sangat setia tehadap layanan produk mesin peralatan otomasi perkantoran tersebut, dan tata letak ruangan memberi dukungan terhadap rasa kenyamanan kerja, sehingga mampu untuk selalu mempertahankan dan memperbaiki performansi diri. Kelihatannya terdapat sesuatu yang membuat pengguna selalu beharap, selalu, tertarik, tidak merasa bosan, waspada, dan cenderung untuk lebih memperhatikan. Tata letak ruang kerja yang telah didesain baik, akan dapat meningkatkan vigilansi pengguna, karena jika ternyata membuat rendah tevel vigilansi ini, maka akan membuat situasional awareness pengguna atau operator menjadi tereduksi, akibat lebih lanjut adalah kemampuan untuk proses pengambilan keputusan juga menurun, tidak ada atensi sama sekali, bored, bum-out atau tidak akan memberikan respon apalagi feedback terhadap proses produks। yang sedang berlangsung. Dengan kata lain, tata letak ruang kerja beserta peralatan otomasi perkantoran di dalamnya, didesain untuk dapat berpenampilan menarik, menyenangkan, dan membuat orang merasa sayang atau bahkan mencintainya, sehingga akan cenderung memberi perhatian yang lebih banyak. Terkait dengan performanisi kerja yang secara langsung akan meningkat, dan produktivitas juga meningkat.

Kesadaran terhadap keberadaan atau situasi yang terkait dengan penggunaan mesin dan peralatan perkantoran di industri oleh operator dalam suatu ruang kerja dengan tata letak yang didesain menjadi lebih baik, merupakan salah satu predictor yang harus, diperhatikan. Sebagai contoh adalah bunyi alarm atau tanda terjadinya kegagalan atau selesainya tahapan dalam proses produksi. Dapat diatur bagàimana bunyi tersebut mampu menggugah semangat atau mengingatkan tehadap kenangan tertentu (regresive), yang akan membuat situasional awareness pengguna menjadi lebih tinggi. Sebagai misal, dengan lagu kesukaannya saat bahan baku kertas atau tinta (misainya) akan habis dan berbeda lagi jika akan selesai proses tertentu, beda lagi jika hanya alarm pengingat waktu, bahkan pesan yang datang dari supervisor atau bos via LAN (Local area network) akan memiliki lagu yang berbeda, fax yang datang atau email juga memberikan nada yang gembira dan lain-lain. Situasional awareness ini terkait juga dengan abilitas operator dalam memahami interaksi terhadap mesin dan peralatan tersebut, terkait dengan tata letak ruang kerja yang disesuaikan dengan karakte- 
ristik (human factor) pengguna. Bagaimana pengguna mempersepsikan element lingkungan yang terkait dengan proses produksi, durasi waktu, ukuran, bentuk, berat, wama, ketermudahan jangkauan dan pengoperasiannya, dan bagaimana pemberian makna, atau proyeksi status alat tersebut (misalnya inputfoutput unit, key-in/boand, or human-computer interface) bagi operator, termasuk kemampuannya untuk mengingatkan terhadap kenangan yang mengesankan dan mampu memotivasi kerja (regresive). Dampaknya adalah performansi kerja operator sebagai pengguna tata letak ruang kerja di industri akan meningkat.

Beban kerja yang ditanggung oleh operator baik yang bersifat mental, kognitif maupun fisik yang tinggi, dapat mengurangi vigilansi dañ situasional awareness, sehingga kecepatan, akurasi dan relevansi proses pengambilan keputusan akan menurun. Workload didefinisikan oleh sanders dan McCormick (1993) sebagai kuantitas yang terukur dari permintaan proses terhadap informasi terkait dengan urutan tugas (task, motion \& time study) operator. Beban kerja yang terlalu rendah juga dapat mengakibatkan rendahnya situasional awareness, kebosanan, dan kejenuhan. Desainer tata letak ruang kerja sudah memperhatikan beban kerja saat operator menggunakan peralatan kantor dan layout hasil produknya. Urutan task sa- at mengoperasikan peralatan otomasi perkantoran, disesuaikan dengan urutan proses kognisi operator tersebut, sehingga tidak akan timbul beban mental, beban psikologis, atau fisik yang berlebihan. Ideainya adalah tidak terialu sulit untuk dioperasikan, tetapi masih dapat memberi tantangan terhadap operator untuk mengeksplore lebih lanjut agar terpenuhi kuriositasnya dan mengalami proses pembelajaran, sehingga akan tetap menimbulkan atensi dan kuorisitas yang terus menerus terhadap tata letak ruang kerja beserta peralatannya terkait hasil proses produksi.

Human error merupakan variable yang cukup penting, terkait dengan kondisi atau situasi yang cenderung akan menimbulkan kecelakaan kerja atau unsafe condition bagi operator (Berry,Lilly.M. 1998). Misalnya ada cagian tertentu dari peralatan atau bagian dari tata letak ruang kerja yang dapat melukai pengguna, dapat membuat pengguna terkena aliran listrik, atau membuat mesin dan peralatan di dalam ruang kerja tersebut mudah rusak. Hal ini terkait dengan persepsi, dan kemudahan operasi terhadap peralatan dalam ruang keda. Selain itu terkait pula dengan ketersediaan pengaman, informasi promotif, prosedur darurat, atau problem solving bila dalam keadaan unsafe condition. Desainer sudah memperhatikan hal im, karena bila terdapat satu kasus 
saja terkait dengan tata letak peralatan pelayanan di ruang kerja dapat sebagai hazarr, maka akan terjadi ancaman yang mengakibatkan pemborosan yang sangat besar terkait dengan kesehatan, kenyamanan, dan keselamatan kerja. Selain itu pengalaman yang tidak menyenangkan, akan menjadi memori negatif yang dapat mengakibatkan phobia tertentu bagi pekerja. Informasi peringatan, user manual atau pedoman pengoperasian terstandar, kondisi yang diharapkan dan yang tidak, harus dapat dipersepsikan dengan jelas, tidak ada ambiquitas, untuk itu sebaiknya perlu didukung dengan penempatan, warna, karakter huruf, peletakan tanda, jenis symbol atau ikon yang jelas, menarik, dan terstandar.

Data penilaian Ahli media pem-belajaran untuk angket tertutup men-dapatkan rerata skor 3.08, simpa-ngan baku 0.282 dengan persentase $77.08 \%$. Data penilaian ahli materi K3, ergonomika dan tata letak, men-dapatkan rerata skor 3.40, simpa-ngan baku 0.498 dengan persentase $85 \%$. Secara keseluruhan tingkat validitas desain tata letak ruang kan-tor pada proses otomasi perkantoran di industri dari penilaian user dikate-gorikan baik dengan presentase $78.175 \%$.

Berdasarkan analisis data penilaian ahli media pembelajaran, ahli materi K3, ergonomika, tata letak dan user media seperti dijabarkan di atas, maka desain animasi tata letak ruang kantor pada proses otomasi perkantoran di industri sangat layak digunakan dengan beberapa revisi, dengan tingkat validitas untuk ahli media pembelajaran sebesar 77 $.08 \%$, tingkat validitas untuk ahli materi $\mathrm{K} 3$, ergonomika dan tata letak sebesar $85 \%$, dan tingkat validitas untuk user sebesar $78.17 \%$.

\section{Penutup}

Berdasarkan uratan di atas telah menunjukkan bahwa banyak sekali faktor yang menunjang produktivitas. dan performansi kerja. Salah satu faktornya adalah tata letak ruang kantor. Apa yang diungkapkan di atas adalah pandangan dari segi kenyamanan, kesehatan dan keselamatan kerja, sehingga mampu meningkatkan produktivitas kerja, meningkatkan vigilansi, situasional awareness, serta mampu menekan beban kerja. Desain ruang kantor inj meliputi dimensi, ukuran, cakupan jangkauan dan tata letak meja kerja, kursi, mesin atau peralatan pendukung lain yang dikaitkan dengan keterbatasan manusia pekerjaannya (human-factor).

Hasil desain ruang kantor di atas adalah salah satu usulan perbaikan dari kondisi ruang kantor yang lama terutama pada ruang proses produksi yang menggunakan otomasi perkantoran di industri yang dituangkan dalam bentuk animasi miltimedia. Harapannya para ope- 
is

rator akan merasa home, senang, nyaman, tidak tertekan, sehingga dapat meningkatkan semangat kerja. Rekomendasi hasil desain ini dapat diterima dengan baik di industri. meskipun tidak dapat diimplementasikan secara langsung dan sebagai implikasinya hasil desain ini dapat digunakan secara nyata oleh pihak industri sebagai materi pelatihan/diklat kesehatan dan keselamatan kerja terkait dengan perancangan tata letak ruang kantor. Ruang kantor yang nyaman, sehat dan selamat, terkait pula dengan penggunaan alat-alat yang disesuaikan dengan antropometri karyawan, dan memperhatikan kaidah manajemen kaizen, sehingga perlu dilakukan redesain tata letak peralatan kerja yang mengacu pada pninsip-prinsip 5S/5R (ringkas, rapi, resik, rawat, dan rajin).

\section{Daftar Pustaka}

Adams,J.A. 1989. Human Factor Engineering.New York :Macmi Ilan PC.

Apple, James M. 1987. Plant Tata letak and Material Handling. New York : John Wiley \& Sons.

Barnes, Ralph M. 1990.Motion and Time Study (Design and Measurement of Work). New York: John Wiley \& Sons.

Berry,Lilly.M.1998. Psychology at Work. Sanfransisco:McGrawHill.Bridger, R.S. Introduction to Ergonomics. Singapore: Mc Graw-Hill,Inc.

Freeman. Roger L2000. Workpla. ce: OSHA is Trying to Regulate Injuries to Employees. bllp://www.dgslaw.com/articles /291568.html

Hirano, Hiroyuki. 1995.Penerapan $5 S$ di Ruang kantor. Jakarta: PQM Consultans. .

ILO. 1968.Ergonomic and Physical Environment Factors. Genewa : International Labour Office.

Cautela and Kearney. 1984. Enggi neering Psychology. dalam Corsim RJ (ed). Encyclopedia of Psychology. Canada:John Wiley \& SON. Inc.

Chapanis. 1976. Engineering Psychology. dalam Dunnette (ed).Handbook of Industrial and Organizational Psychology. Chicago:Rand McNally.

Davis. W. S., 1983.System Analysis and Design a Structured Approach. Massachusetts: Wesley Addison.

Jefrey.LW., Lonnie. DB. \&Thomas.

IM. 1986. System Analysis and Design Methods. St.Louis:

Time Mirror-Mosby CP.

Kolarik. 1995.Creating Quality .International EdMcGraw-Hill

Ismara, Kl.2002 Integrated Redesign ofA utomation System and Work Environment to Improve Productivity. Laporan Penelitian Mandiri. 
Ismara,K1.2005 Human-Machine Interaction dalarn kajiian Aspek Psikologi Teknologi. Laporan Penelitian Mandiri.

NIOSH.2005. Musculetal Disoders and Workplace Factor. Download 22 Januari 2005. http: //www.ede.goy/NIOSIl/homepage.html.

Osmond. Inc.2005. Osmond Ergonomics Workplace Solution. Download 14 Februari 2005

Htp://www.ergoergo.info/workstation. html

Panero, Julius and Zelnik, Martin. 1980. Human Dimension and interior Space: A Source Book of Design Reference Standarts. USA: Whitney Library of Design.

Pulat, Mustafa. 1992. Fundamentals of Industrial Ergonomics. New Jersey: Prentice Hall.

Sutalaksana, Anggawisastra dan Tjakraatmaj'a.1989. Teknik dan Tata Cara Kerja. Bandung: ITB.

Sutopo, Ariesto Hadi. 2002. Animasi dengan Macromedia di Industri Berikut Actionscript. Jakarta: Salemba Infotek.

Sastrowinoto, S.1985. Meningkatkan Produktivitas dengan Ergonomi. Jakarta: PT. Pratnja.

Stemberg. 1999. Cognitive Psychology. Yale:Harcourt BC. Pub.

Sugiyanto. 2000. "Otomatisasi di Dunia Kerja dan Industri, "Procee ding Ergonomi 2000 (Sritomo
Wignjoscebroto \& WirAtno, ed). Surabaya: Guna Widya.

Suzaki,Kiyoshi. 1997. The New Manufacturing Challenge: Techniques for Continuing Improvement. California: Diamond Pub.Comp.

UsabilityNet.2003 (online), what is usability. available in htlp:/l ",Ww, usabilitynet.or ,

Wickens and Holland. 2000. Enggeering Psychology and Human Performance.New Jersey Prentice Hall

Wignjosoebroto, Sritomo-.2000.Ergonomi, Studi Gerak dan Wak. tu: Teknik Analisis untuk Peningkatan Produktivitas Kerja. Edisi 1 Cetakan kedua. Surabaya Guna Widya.

WHO. 1995.Deteksi Dini Penyakit Akibat Kerja. Jakarta: Penerbit Buku Kedokteran EGC.

Woodside, G and Kocurek, D. 1997. Enviromental, Safefy, and Health Engineering. New York: John Wiley \& Sons.

muw. ccosh.cam/workarea

wmw.Apple.com/about/ergonomicl workarea tata letak

www.apple.com/about/ergonomics/e yes and vision

\section{Biodata}

$\mathrm{KI}$ Ismara, HP.08156860566, ki ismara@yahoo.com; Ji.Taman Siswa 18 Jogja, lektor kepala di bidang pendidikan kejuruan, teknologi, dan industri FT UNY, meraih magister 
Manajemen Pendidikan, dengan minat utama diklat di industri dari UNK dan magister Kesehatan Kerja Industri dari Fakultas Kedokteran UGM. 